\title{
日本クリティカルケア看護学会の設立を祝って
}

\section{有賀 徹}

日本臨床救急医学会理事長

昭和大学医学部教授救急医学講座主任

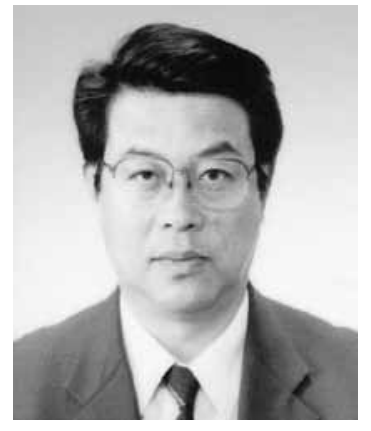

日本クリティカルケア看護学会会員そして日本クリティカルケア看護学会誌を読 まれている皆様には常日頃からこの領域ならびに関連する諸分野において大いに活 躍されておりますことに，まずは感謝と尊敬の念を表したく思います，厚く御礼申 し上げます。

さて，日本クリティカルケア看護学会の設立にあたり，ここにお祝いの言葉を申 し上げます。おめでとうございます。ここに至るまでには多くの方々の御努力に加 えて団結と調和のお心，お力があってのことと深く敬意を表したく思うところであ ります。すでに設立趣意書にありますように，看護に携わる方々の活躍は極めて多 岐にわたっております。そして, 多くの領域において専門看護師の認定が為されて いることなども合わせて考元ますれば，国民の求める医療分野，看護分野において 絶大なる貢献をされてきたことも周知であります。また，クリティカルケアという 言葉がしばしば急性期の重篤な, 例えば緊急手術となった救急患者の集中治療と いった局面などに用いられてきた傾向を否めないときに，貴学会の趣旨によれば， 在宅医療や終末期の場面においてもクリティカルケア看護の実践があることに大い なる慧眼を感じずにはいられません。

そもそも患者には主治医がいて，その主治医の指示のもとに多くの職種が役割を 分担しながら医療が展開するという基本的なルールは確かにその通りであると言え ばその通りでしょうが，病院の中のみならず，社会一般で行われている医療，また は医療に近い諸々の行為は関係する多くの職種が，まさにチームとしてスクラムを 組んで展開しているといっても過言ではありません，私の職場である救命救急セン ターにおける医療についても, 入院の冒頭から医療福祉土や薬剤師の直接的な関与 が求められることは稀ではありませんし, 鱑下や栄養, 裖創, 口腔ケア等々と急性 期から包括的かつ継続的な医療を展開しょうとすれば，まさに病院の中のみならず 
地域の行政を含めた多くの施設などとの連携を密にせねばなりません. 日本臨床救 急医学会は医師，看護師，救急隊員を含めた多くの職種が同等の資格で参加し議論 し合い，同じ価値観で研鑽を積もうという学会です．今回私に名誉ある祝辞のお役 目を賜つたのは, 貴学会の趣旨が今述べたチーム医療や日本臨床救急医学会におけ る考え方，またはそのようにして展開する医療の方法論を包含しているからのよう に思われます。クリティカルケア看護学の実践はそのような価值体系の上に成り 立っていくものと信じます.

加えて, 貴学会の趣旨にはクリティカルケア看護学に関する教育・研究の側面へ の言及があります。これらのことは，例えば我が国における在宅医療や終末期のあ り方などに思いを馳せれば，未知の分野が少なくないであろうことは想像に難くは ありません。しかし，患者の幸福を考える多くの実践の中から多くの問題が芽生え， それを解決しょうとする営みが教育や研究と無関係なはずはさらさらありません。 むしろ，現場から教えられ学んだことを同世代で共有し，そして次の世代に伝える ということがあれば, それこそがクリティカルケア看護学の発展であり, 患者や社 会にとっての福音であるという自負をこそ持たれるべきと心から思う次第です.

貴学会会員ならびに関係各位におか扎ましては，ここに述べました洋々たる前途 に向かい是非とも奮励努力をされて, 我々の社会に大きく裨益されんことをここに 希うものであります。日本クリティカルケア看護学会会員皆々様の御活躍と日本ク リティカルケア看護学会の御発展を心からお祈り申し上げます. 